\title{
$\mathrm{ECAP}$ - 熱間押出加工法による $\mathrm{SiC}$ 粒子分散 AZ31B マグネシウム 合金切削チップ複合材料の作製とその機械的性質
}

\author{
會田 哲夫 * ·高辻 則夫 * ・松木 賢司* \\ 佐藤 环磨 $* *$. 鎌土 重晴 $* * *$
}

Journal of Japan Institute of Light Metals, Vol. 58, No. 3 (2008), pp. 104-110

\section{Mechanical properties of SiC particle-AZ31B magnesium alloy machined chips composites prepared by hot extrusion after ECAP}

\author{
Tetsuo AIDA*, Norio TAKATSUJI*, Kenji MATSUKI* \\ Takuma SATOU** and Shigeharu KAMADO***
}

\begin{abstract}
Wear resistance and mechanical properties of hot extruded $\mathrm{AZ31B} / \mathrm{SiC}$ particle composite, where the hot extrusion billets were processed by ECAP, were investigated. Uniform dispersion of $\mathrm{SiC}$ particles was observed after extrusion for the mean particle size of $1.2 \sim 11 \mu \mathrm{m}$ constituting 0 to $6 \%$ volume fraction of $\mathrm{SiC}$ particle content, where the particles had been thinly adhered to the surface of the machined chips of ECAP-hot extrusion samples before extrusion. However, when the $\mathrm{SiC}$ particle size is under $3 \mu \mathrm{m}$, the aggregates at the triple junction of the interfaces of the machined chips could not be decomposed and dispersed. To solve this problem, hot extrusion was carried out using various cold green compacts prepared by repetitive ECAP processed up to 7 times. As a result, refinement of grain size was obtained for the ECAP extruded materials by decomposition and dispersion of the SiC particles with increase in the ECAP frequency. Consequently, it was possible to obtain the composite of AZ31 magnesium base alloy machined chip and SiC particle which contains almost uniformly dispersed $\mathrm{SiC}$ particles. Furthermore, the average grain diameter of the matrix was very much refined to approximately $2 \mu \mathrm{m}$, and $\sigma_{\mathrm{B}}, \sigma_{0.2}$ were also improved. Frictional wear test shows that abrasion resistance was further improved for $N=7$ extruded materials than $N=4$ samples due to more homogeneous mixing of the $\mathrm{SiC}$ particles as well as decomposition and dispersion of the aggregates.
\end{abstract}

(Received August 30, 2007 Accepted November 6, 2007)

Keywords: $M g$, AZ31 magnesium alloy, machined chips, SiC, extrusion, ECAP

\section{1. 緒言}

マグネシウムは実用金属の中で最も密度が低いことから， 自動車をはじめとする輸送用機器の軽量化対策において魅力 のある材料である ${ }^{1)}$ 。しかし, 実際の使用に際しては耐摩耗 性や剛性の向上が必要となることが多い2),3)。

耐摩耗性, 弾性率, 耐熱性等を向上するためには, 従来か ら $\mathrm{SiC}_{\mathrm{W}}{ }^{4), 5)}, \mathrm{SiC}_{\mathrm{P}}{ }^{6), 7)}, \mathrm{TiC}^{8)}, \mathrm{SiO}_{2}^{9), 10)}$ 等を混合した複合材料 の報告例がある。その製造方法として, 溶湯攪拌法, 溶湯鍛 造法, MA 法などが挙げられるが，これらの方法では発火の 危険性, 溶湯時の酸化保護ガスとして使用される六ふっ化硫 黄 $\left(\mathrm{SF}_{6}\right)$ の使用規制, 鉄やニッケル等の不純物元素の混入 による耐食性の劣化, 比重差における不均一な混合等, 様々 な問題点がある11)。それに対して溶湯を使用しない塑性加工 を利用した固化成形法は，高機能なアップグレードリサイク ル化 ${ }^{12)}$ が可能であり，地球環境にとっても優れた製造技術
といえる。

著者らはこれまでに，マグネシウム製品の製造工程で生じ るマグネシウム切削くず（以下，切削チップと呼称する）を 出発原料として熱間押出加工することにより, 均質な押出材

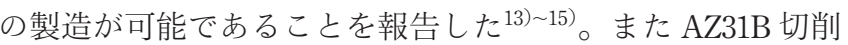
チップに繰返し ECAP加工を施すことにより, 均質な引張特 性を有する固化材が得られることも明らかにしている16)。近 藤ら ${ }^{17)}$ は, AZ31 切削チップに 5 mass $\%$ Si を添加してバルク メカニカルアロイング（BMA）を行った後, 押出加工を施す ことで $\mathrm{Mg}_{2} \mathrm{Si}$ の分散を図り, $\sigma=378 \mathrm{MPa}, E_{\mathrm{L}}=11 \%$ を有する 押出材が得られることを報告している。そのほかにあ RCP工 法 ${ }^{18)}$, ねじり押出加工 ${ }^{19)}$, 繰返し ECAP 加工 ${ }^{20)}$ などの微細 結晶粒化に関する報告例は多数あるが, 強化粒子の複合化と リサイクル化の観点から繰返し ECAP加工後に熱間押出 ${ }^{21,22)}$ を行い, 強化粒子分散の均質化 ${ }^{23)}$ に関する系統的な研究報 告例は少ない。

*富山大学大学院 理工学研究部（＝ 930-8555 富山市五福 3190)。Graduate School of Science and Engineering for Research, University of Toyama (3190 Gofuku, Toyama-shi, Toyama 930-8555).

**富山大学大学院 理工学教育部（富山市)。Graduate School of Science and Engineering for Education, University of Toyama (Toyama-shi, Toyama).

***長岡技術科学大学 機械系 (長岡市)。Department of Mechanical Engineering, Nagaoka University of Technology (Nagaoka-shi, Niigata). 
本研究では，AZ31B マグネシウム合金切削チップと $\mathrm{SiC}$ 粒 子を混合した冷間圧粉体に対して繰返し ECAP 加工を施し, 強せん断加工により $\mathrm{SiC}$ 粒子の凝集体の分断および分散を促 進し，さらにこの ECAP 固化材に対して熱間押出を加え，一 層均質に分散した $\mathrm{SiC}$ 粒子複合押出材の創製と室温における 機械的性質および而摩耗性を検討した。

\section{2. 実験方法}

\section{1 切削チップの粉砕混合と冷間圧粉体}

本実験は，市販の AZ31B 鋳造ビレット材（ $\phi 155 \mathrm{~mm})$ を旋 盤により, 回転数 $560 \mathrm{rpm}$, 切込み量 $0.7 \mathrm{~mm}$ の条件で外周切 削加工して長さ約 $7 \mathrm{~mm}$ の切削チップを採取した後, 卓上 ポットミル回転台により粉砕混合して長さが約 $3 \mathrm{~mm}$, 幅が $1 \mathrm{~mm}$, 厚さが約 $0.3 \mathrm{~mm}$ の均質な切削チップを作製した。こ の切削チップの外観形状を Fig. 1 (a) に示す。その後, 昭和 電工(株製の 3 種類の $\mathrm{SiC}$ 粒子（粒子径： $d_{\mathrm{P}}=1.2 \mu \mathrm{m}, 3 \mu \mathrm{m}$ お よび $11 \mu \mathrm{m})$ を体積率： $V_{\mathrm{f}}=0 \sim 6 \%$ の範囲で添加し, 再度 ロッドミルにて混合を行った。冷間圧粉成形体は 30 ton アム スラー型万能試験機を用いて室温にて成形荷重 : $\sigma_{\mathrm{P}}=388$ $\mathrm{MPa}$ ，保持時間： $t_{\mathrm{p}}=360 \mathrm{~s}$ とし, Fig. 1 (b) に示すような $D=$ $30 \mathrm{~mm}, L=50 \mathrm{~mm}$ の冷間圧粉体を作製した。

\subsection{ECAP 加工}

冷間圧粉体を溝孔の交差角： $\phi=105^{\circ}$, 曲面部のコーナ 角： $\Psi=33^{\circ}$ の $\mathrm{ECAP}$ 金型16) に投入し, $\mathrm{ECAP}$ 温度 : $T_{\mathrm{ECAP}}=$ $673 \mathrm{~K}$ で，まず無潤滑で $N=1$ 回の ECAP 加工を加えた。その 後, $\mathrm{MoS}_{2}$ 系潤滑剂を塗布し, $T_{\mathrm{ECAP}}=623 \mathrm{~K}$ にて繰返し回数： $N=2 \sim 7$ 回の ECAP 加工を行った。繰返し時の試験片回転角 (R) は X 軸, $\mathrm{Y}$ 軸方向にともに結晶粒が伸長するとされてい る Route $\mathrm{B}_{\mathrm{A}}{ }^{24)}$ を採用し $R=90^{\circ}$ とした。その際のひずみ理論 值 $\left(\varepsilon_{\mathrm{N}}\right)$ は, Iwahashi らが提唱した式 ${ }^{25), 26)}$ を用いて算出し た結果， $\varepsilon_{\mathrm{N}}=0.80 N^{16)}$ であった。

\section{3 ECAP - 熱間押出}

$\mathrm{ECAP}$ - 熱間押出加工に用いた押出ビレットは, $N=1$ 回, 4 回および 7 回の ECAP加工を施した後, 固化材表面に付着し ている潤滑剂を除去してから使用した。押出装置として 400 トン縦型油圧プレス機（不二越製：400T型）を用い，押出 温度 : $T_{\mathrm{E}}=573 \mathrm{~K}$, 押出比 : $R=47$, 押出ラム速度 : $V_{\mathrm{R}}=0.5$ $\mathrm{mm} / \mathrm{s}$ で板厚 : $t=1.5 \mathrm{~mm}$, 幅 : $w=11.4 \mathrm{~mm}$ の押出板材を作製 した。

\section{4 ミクロ組織観察}

ECAP材および押出材の縦断面ミクロ組織観察には, 光学 顕微鏡および走査電子顕微鏡（日本電子(株)製：JSM-6700F） を用いた。まず $\mathrm{SiC}$ 粒子の分散状態は, \#80 \#1500 番のエメ リ一紙を用いて水研磨し, その後順次, $\mathrm{Al}_{2} \mathrm{O}_{3}, \mathrm{MgO}$ およびコ ロイダルシリカのけん濁液を用いたバフ研磨で鏡面仕上げを 行い，腐食せずに走査電子顕微鏡により観察した。また結晶 粒径の測定には，鏡面仕上げ後，ピクリン酸： $3.25 \mathrm{~g}$ ，エ夕 ノール： $54 \mathrm{ml}$, 酢酸： $2.5 \mathrm{ml}$, 蒸留水： $5.5 \mathrm{ml}$ の混合液を用 いて腐食し, 光学顕微鏡で行った。なお平均結晶粒径は切片 法により測定した。

\section{5 機械的性質}

引張試験片は, 押出形材の先端から約 1 1.5 m の箇所を押 出方向に平行に採取し, 標点距離 : G.L. $=12 \mathrm{~mm}$, 幅 : $w=4$ $\mathrm{mm}$, 厚さ： $t=1.5 \mathrm{~mm}$ となるように超硬エンドミルを用いて
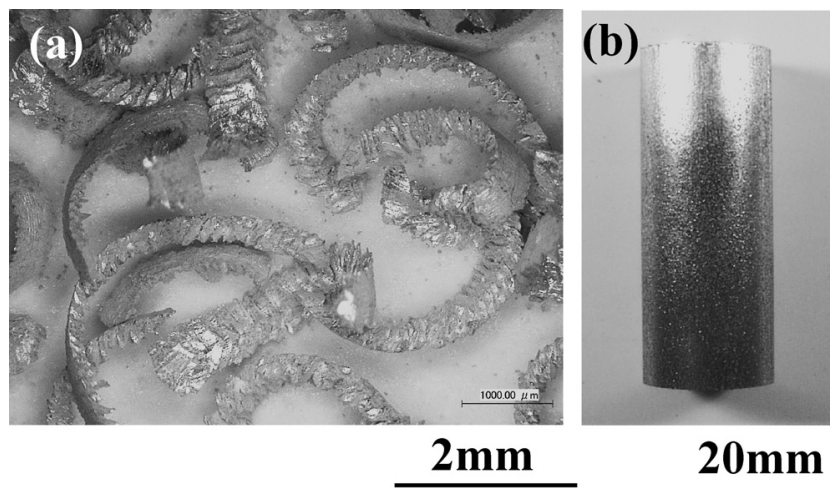

Fig. 1 (a) machined chips, (b) compressed sample before hot extrusion. $\left(P=388 \mathrm{MPa}, T_{\mathrm{P}}=\right.$ R.T. $)$

フライス加工を行った。室温における引張試験は, オートグ ラフ（島津試験機製； AG-50kNG 型）を用いて, 初期ひずみ 速度： $\dot{\varepsilon}=7 \times 10^{-4} \mathrm{~s}^{-1}$ （クロスヘッドスピード：0.5 mm/min） の条件下で行い, 引張強さ： $\sigma_{\mathrm{B}}, 0.2 \%$ 耐力: $\sigma_{0.2}$, 破断伸 び： $E_{\mathrm{L}}$ を求めた。破断面およびその近傍む SEM よる観察を 行った。

ビッカース硬さ試験は，微小硬さ計（フューチュアテック 製：FM-700）を用い, 印加荷重を $1.96 \mathrm{~N}$, 印加時間を $15 \mathrm{~s}$ と して 10 箇所の测定を行い，その最大值および最小值を取り 除いた 8 点の平均值を $\mathrm{HV}$ 值とした。

\section{6 摩擦摩耗試験}

摩擦摩耗試験は, ローラ・チップ型摩擦摩耗試験機 27) を 用い, 大気中, 無潤滑にて行った。摩擦摩耗試験に用いた試 験片は, $T_{\mathrm{ECAP}}=623 \mathrm{~K}$ で $N=4$ 回および $N=7$ 回の $\mathrm{ECAP}$ 加工 を施した後に $T_{\mathrm{E}}=573 \mathrm{~K}$ で熱間押出した押出材から押出方向 に対して平行に採取した。長さは $5 \mathrm{~mm}$, 幅は $11 \mathrm{~mm}$, 厚さ は $1.5 \mathrm{~mm}$ とした。 $N=4$ 材では $V_{\mathrm{f}}=6 \%$ における $\mathrm{SiC}$ 粒子径の 影響, $N=7$ 材では $d_{\mathrm{p}}=3 \mu \mathrm{m}$ とした $V_{\mathrm{f}}$ の影響を調査した。相 手材は直径 $30 \mathrm{~mm}$, 幅 $12 \mathrm{~mm}$ の FC250 鋳鉄製の回転ローラと した。試験装置は FC250 鋳鉄製の回転ローラの外周面上に ECAP-熱間押出材を押出方向に対して垂直方向に一定荷重 となるように押付けて摺動する仕組みとなっている ${ }^{27)}$ 。試験 条件は, 試験片の押付荷重 : $P_{\mathrm{W}}=98 \mathrm{~N}$, 摩擦速度 : $V_{\mathrm{W}}=0.05$ $\mathrm{m} / \mathrm{s}$, 摺動距離 : $L_{\mathrm{W}}=37.7 \mathrm{~m}$ とした。測定方法は試験前後の 試験片重量を精密電子天秤により計測し, その差を摩耗量と して行った。またローラの試験前後の重量む同様に計測した。

\section{3. 実験結果および考察}

\section{1 冷間圧粉体のミクロ組織}

Fig. 2 (a) と（b）に， SiC 粒子径 $1.2 \mu \mathrm{m}$ を体積率 $6 \%$ とな るように添加した冷間圧粉体の縦断面における $\mathrm{SiC}$ 粒子の分 布状態を，光学顕微鏡と SEMにより観察した結果を示す。 Fig. 2 (a) には旋盤加工により生成した切削チップの鋸歯状 界面に黒い領域が認められる。この切削チップ界面の 3 重点 付近を SEM により拡大した結果を Fig. 2 (b) に示しており, $\mathrm{SiC}$ 粒子が多く凝集している部分であることがわかる。

\section{2 熱間押出材のミクロ組織}

Fig. 3(a)〜 (c) に SiC 粒子径 $1.2 \mu \mathrm{m}, 3 \mu \mathrm{m}$ および $11 \mu \mathrm{m}$ の 3 種類を体積率が $6 \%$ となるように作製した冷間圧粉体に対し て, 押出温度 : $T_{\mathrm{E}}=573 \mathrm{~K}$, 押出ラム速度 : $V_{\mathrm{R}}=0.5 \mathrm{~mm} / \mathrm{s}$ に 


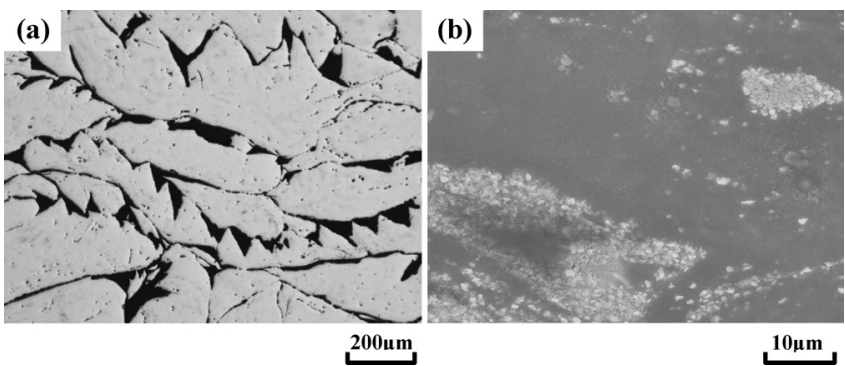

Fig. 2 Photographs of machined chips of AZ31B magnesium alloy after compaction at room temperature. (a) Optical micrograph and (b) SEM photograph.

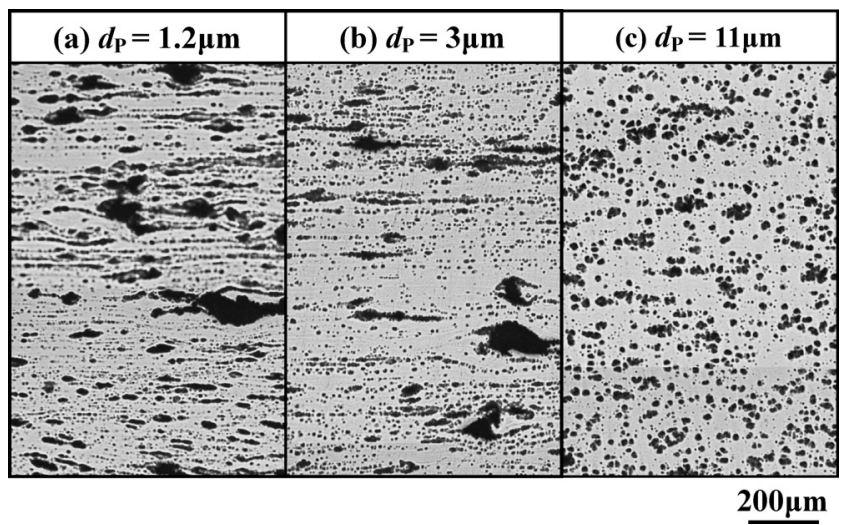

Fig. 3 Optical micrographs of extruded $\mathrm{SiC}_{\mathrm{P}} / \mathrm{AZ} 31 \mathrm{~B}_{\text {chip }}$ composite. SiC particle size, $d_{\mathrm{p}}$, are (a) $1.2 \mu \mathrm{m}$, (b) $3 \mu \mathrm{m}$ and (c) $11 \mu \mathrm{m}$, respectively. $\left(T_{\mathrm{E}}=573 \mathrm{~K}, V_{\mathrm{R}}=0.5 \mathrm{~mm} / \mathrm{s}, R=\right.$ $47, V_{\mathrm{f}}=6 \%$ )

て熱間押出加工した押出材の縦断面中央部における $\mathrm{SiC}$ 粒子 の分散状況を光学顕微鏡（OM）により観察した結果を示す。 $\mathrm{SiC}$ 粒子径 $1.2 \mu \mathrm{m}$ （Fig. 3 (a)）および $3 \mu \mathrm{m}$ （Fig. 3 (b)）の押 出材では $\mathrm{SiC}$ 粒子凝集体が多く観察される。しかし $\mathrm{SiC}$ 粒子 径 $11 \mu \mathrm{m}$ では凝集体はほとんど観察されず， $\mathrm{SiC}$ 粒子がほぼ 均一に分散していることがわかる。

この熱間押出において， $\mathrm{SiC}$ 粒子径が小さい場合の凝集体 の分散挙動を調べるため，Fig. 4(a) に， SiC 粒子径が $1.2 \mu \mathrm{m}$ で，体積率が $6 \%$ の押出材のディスカード縦断面組織観察を 示す。ディスカードは熱間押出を中断しコンテナ内から取出 した。Fig. 4 (a)の (1) (4) は, Fig. 4 (b) に示した観察位置を示 す。Fig. 4 (a)の (1) は観察箇所が熱間押出材のディスカードの 上部であるため，あまり塑性変形を受けておらず Fig. 2 (a) で示した変形前の冷間圧粉体とほぼ同様な切削チップ形状の

ミクロ組織を有している。(2)は塑性変形領域（III）のミクロ 組織であり，切削チップが押出方向に引伸ばされている。(3) はせん断領域（II）のミクロ組織であり, 切削チップのせん断 が著しく生じており，それに伴って $\mathrm{SiC}$ 粒子を含む凝集体の 分断および $\mathrm{SiC}$ 粒子の分散が生じていることがわかる。しか し Fig. 4 (a) の (4)のダイス出口付近においては, SiC 粒子を多 く含む凝集体が完全な分断までには至っていなかった。しか しその中でもせん断組織（II）から流れ込んだ部分では，凝集 体の分断が比較的進んでいるように見える。この凝集体をさ らに分断するには，機械的な強せん断加工を付与することが 必要といえる。そこで次に, 繰返し ECAP 加工したビレット の検討を行った。 (a)

(b) I : Dead metal zone II : Internal shearing zone III: Plastic deformation zone

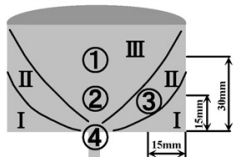

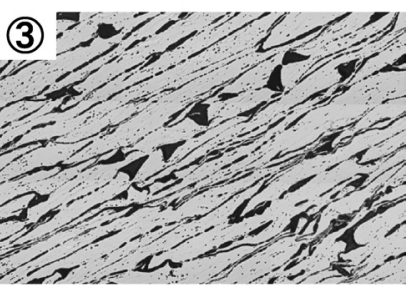

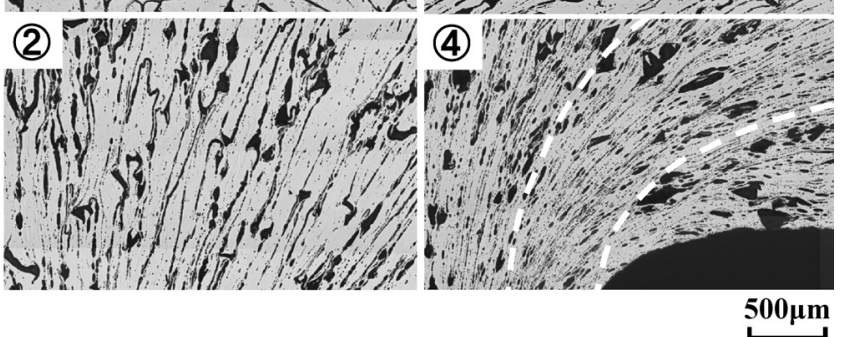

Fig. 4 Optical micrographs showing changes in the metal flow of billet during extrusion of $\mathrm{SiC}_{\mathrm{P}} / \mathrm{AZ} 31 \mathrm{~B}_{\text {chip }}$ composite. Observed positions for (a) are shown in (b), schematically.

\section{3 ECAP 加工材のミクロ組織}

Fig. 5 (a) ( (c) に $\mathrm{SiC}$ 粒子径が $1.2 \mu \mathrm{m}, 3 \mu \mathrm{m}$ および $11 \mu \mathrm{m}$ の 3 種類を $T_{\mathrm{ECAP}}=623 \mathrm{~K}$ で体積率 $6 \%$ における $\mathrm{ECAP}$ 回数 : $N=4$ 回の $\mathrm{ECAP}$ 方向に垂直な縦断面 $\mathrm{OM}$ 組織を示す。 $\mathrm{SiC}$ 粒 子サイズの大きい $11 \mu \mathrm{m}$ 材は若干の塊が認められるあのの, $N=4$ 回で凝集体はほとんど観察されない。しかし $1.2 \mu \mathrm{m}$ 材 は凝集体が带状に薄片化されているものの凝集している箇所 ああることから, $N=4$ 回よりも, さらに繰返し ECAP 加工に よるせん断加工を加え, 凝集体を分断する必要があることが わかった。

\subsection{ECAP- 熱間押出材のミクロ組織}

Fig. $6(\mathrm{a}) \sim(\mathrm{d})$ に粒子径 $3 \mu \mathrm{m}$ の $\mathrm{SiC}$ 粒子を体積率 $6 \%$ で 混合した冷間圧粉体を $T_{\mathrm{ECAP}}=623 \mathrm{~K}$ で $N=1$ 回および $N=7$ 回 の $\mathrm{ECAP}$ 加工を施した $\mathrm{ECAP}$ 固化材に, $T_{\mathrm{E}}=573 \mathrm{~K}$ で押出加 工した縦断面ミクロ組織を示す。 $N=1$ 回の Fig. 6 (a) では, $\mathrm{SiC}$ 粒子の凝集体が存在しており, 拡大した Fig. 6 (c) の領域 においても $\mathrm{SiC}$ 粒子は分散しておらず， $N=4$ 回でも同様の不 均一な箇所が認められた。しかし $V_{\mathrm{f}}=6 \%$ 添加した繰返し ECAP 回数が $N=7$ 回の Fig. 6 (b) 押出材では, 約 $20 \mu \mathrm{m}$ の凝 集体は若干観察されるものの, Fig. 6 (d) の拡大した領域では Fig. 6 (c) に比べて $\mathrm{SiC}$ 粒子が均質に分散していることがわか る。これにより繰返し ECAP 加工による強せん断变形が $\mathrm{SiC}$ 粒子の分散に著しく効果的であることがわかった。

\section{5 室温における機械的性質}

Fig. 7 (a) （c）に， SiC 粒子径が $3 \mu \mathrm{m}$ で体積率を $6 \%$ とし た冷間圧粉体に $T_{\mathrm{ECAP}}=623 \mathrm{~K}$ で（a） $N=1$ 回と（b） $N=7$ 回 施した ECAP 固化材, および (c) $N=7$ 回まで ECAP 加工を 施した後, $T_{\mathrm{E}}=573 \mathrm{~K}$ で押出加工した形材のミクロ組織観察 とその平均結晶粒径サイズを示す。 $\mathrm{ECAP}$ 回数を $N=1$ から $N=7$ 回まで増加することで, Fig. 7 (b) および（c）では黒く 見える $\mathrm{SiC}$ 粒子が均一に分散していることが認められる。特 

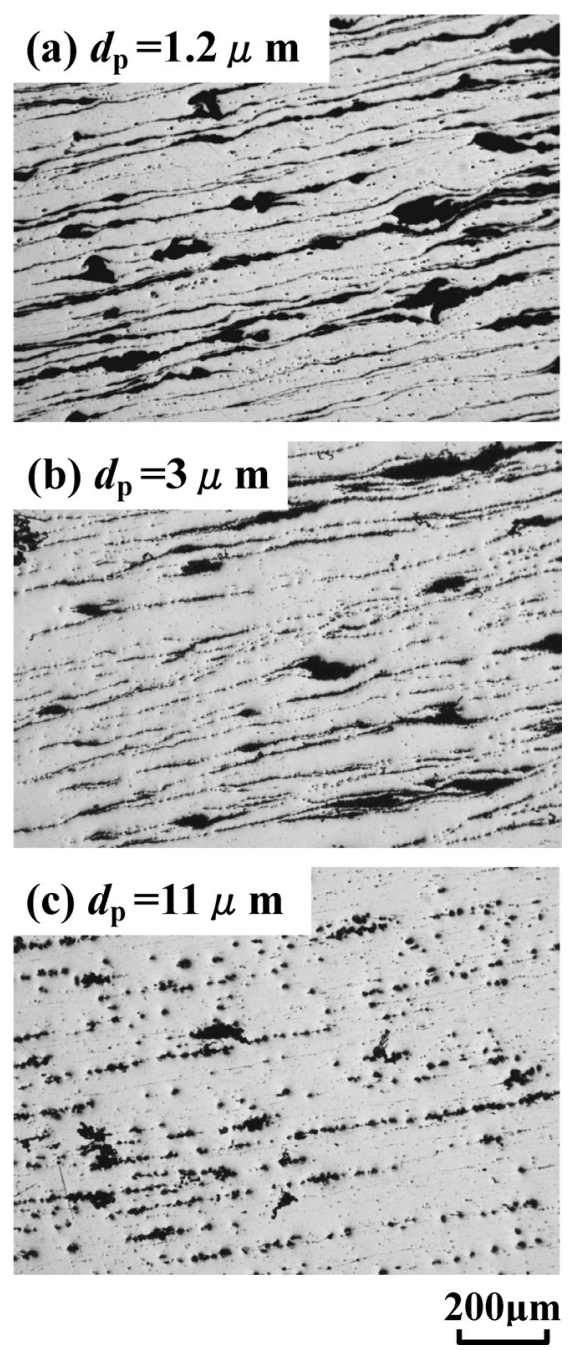

Fig. 5 Optical micrographs of ECAP samples of $\mathrm{SiC}_{\mathrm{P}} /$ $\mathrm{AZ31B}_{\text {chip }}$ composite $\left(N=4, V_{\mathrm{f}}=6 \%\right)$. SiC particle size, $d_{\mathrm{p}}$, are (a) $1.2 \mu \mathrm{m}$, (b) $3 \mu \mathrm{m}$ and (c) $11 \mu \mathrm{m}$, respectively.

\section{Extrusion direction}
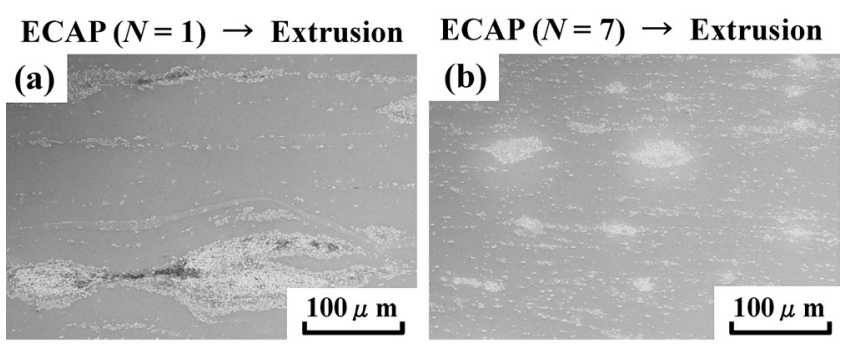

(c)

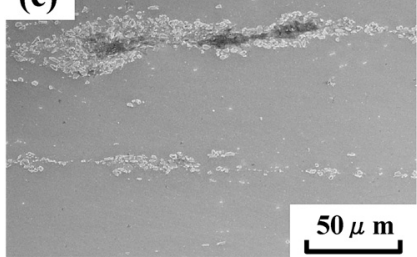

(d)

Fig. 6 SEM micrographs of cross section of $\mathrm{SiC}_{\mathrm{P}} / \mathrm{AZZ31B}_{\text {chip }}$ composites extruded at $573 \mathrm{~K}\left(V_{\mathrm{R}}=0.5 \mathrm{~mm} / \mathrm{s}, R=47\right)$ after ECAP was carried out at $623 \mathrm{~K}\left(N=1, N=7, d_{\mathrm{p}}=3 \mu \mathrm{m}\right.$, $V_{\mathrm{f}}=6 \%$ ). (c) and (d) are enlarged views of same sample as in (a) and (b).
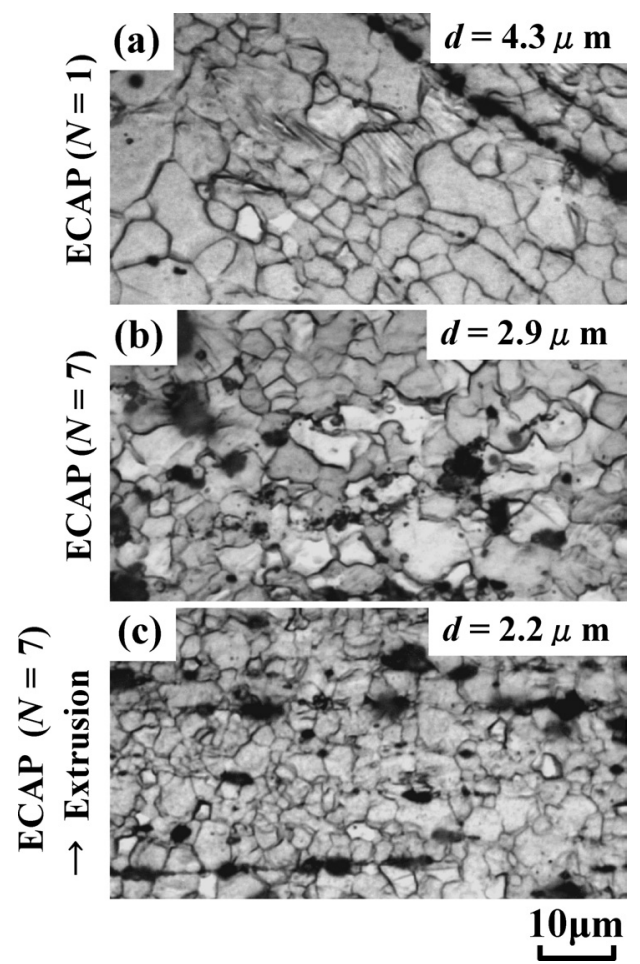

Fig. 7 Optical micrographs of $\mathrm{SiC}_{\mathrm{p}} / \mathrm{AZ} 31 \mathrm{~B}_{\text {chip }}$ composite $\left(d_{\mathrm{p}}=3 \mu \mathrm{m}, V_{\mathrm{f}}=6 \%\right)$. (a) as $\operatorname{ECAP}\left(T_{\mathrm{ECAP}}=623 \mathrm{~K}, N=1\right)$, (b) as ECAP $\left(T_{\mathrm{ECAP}}=623 \mathrm{~K}, N=7\right),(\mathrm{c})$ as extruded at $573 \mathrm{~K}$ after $\operatorname{ECAP}\left(T_{\mathrm{ECAP}}=623 \mathrm{~K}, N=7\right)$.

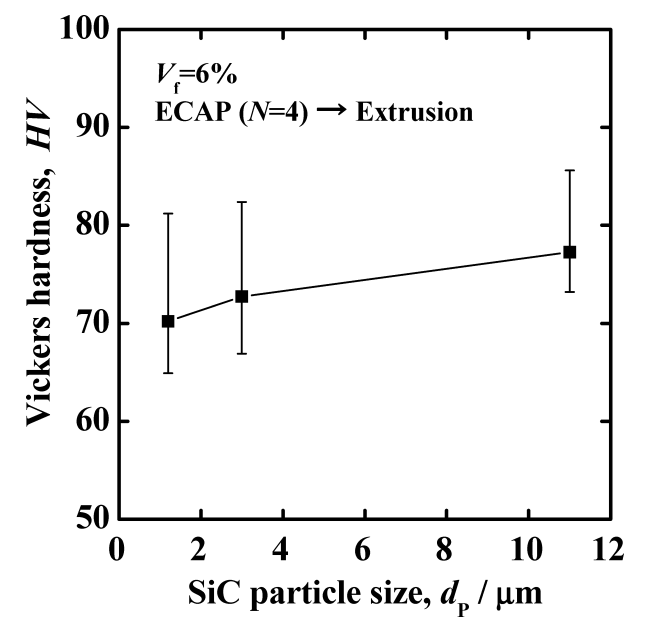

Fig. 8 Micro-Vickers hardness value of $\mathrm{SiC}_{\mathrm{p}} / \mathrm{AZ} 31 \mathrm{~B}_{\text {chip }}$ composites extruded at $573 \mathrm{~K}$ after ECAP processing at $623 \mathrm{~K} . \quad\left(N=4, V_{\mathrm{f}}=6 \%\right)$.

に結晶粒径は $d=4.3 \mu \mathrm{m}$ から $\mathrm{d}=2.9 \mu \mathrm{m}$ にまで微細化し， $N=7$ 回の ECAP 固化材をさらに熱間押出加工することにより $d=$ $2.2 \mu \mathrm{m}$ と更に微細化が可能となった。

Fig. 8 に, 粒子径 $1.2 \mu \mathrm{m}, 3 \mu \mathrm{m}$ および $11 \mu \mathrm{m}$ の $\mathrm{SiC}$ 粒子を 体積率 $6 \%$ となるように添加した 3 種類の冷間圧粉体を $T_{\mathrm{ECAP}}=623 \mathrm{~K}$ で $N=4$ 回の $\mathrm{ECAP}$ 加工を施した後, $T_{\mathrm{E}}=573 \mathrm{~K}$ で押出加工した複合材のビッカース硬さ試験結果を示す。 $\mathrm{SiC}$ 粒子径サイズが大きくなるほど, ビッカース硬さは増大する 傾向にあることがわかった。これは Fig. 3 で示したが, SiC 粒 子径の比較的大きい $11 \mu \mathrm{m}$ では，凝集体とはならずに比較的 均一な分散を生じており, $\mathrm{SiC}$ 粒子の表面がマトリックスと 


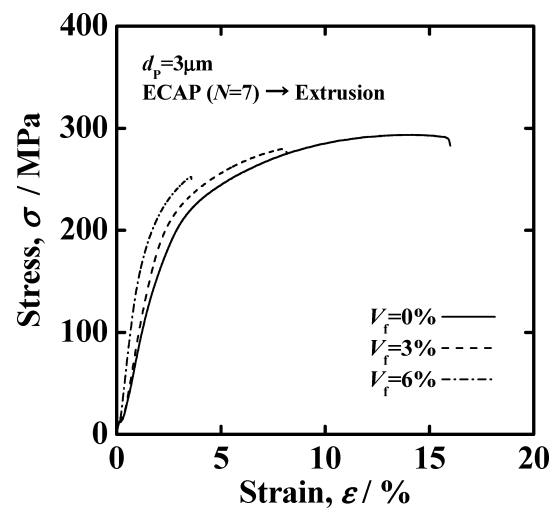

Fig. 9 Effect of volume fraction of $\mathrm{SiC}_{\mathrm{P}}$ on stress-strain curves for extruded $\mathrm{SiC}_{\mathrm{P}} / \mathrm{AZ} 31 \mathrm{~B}_{\text {chip }}$ composites after ECAP $(N=7)$.

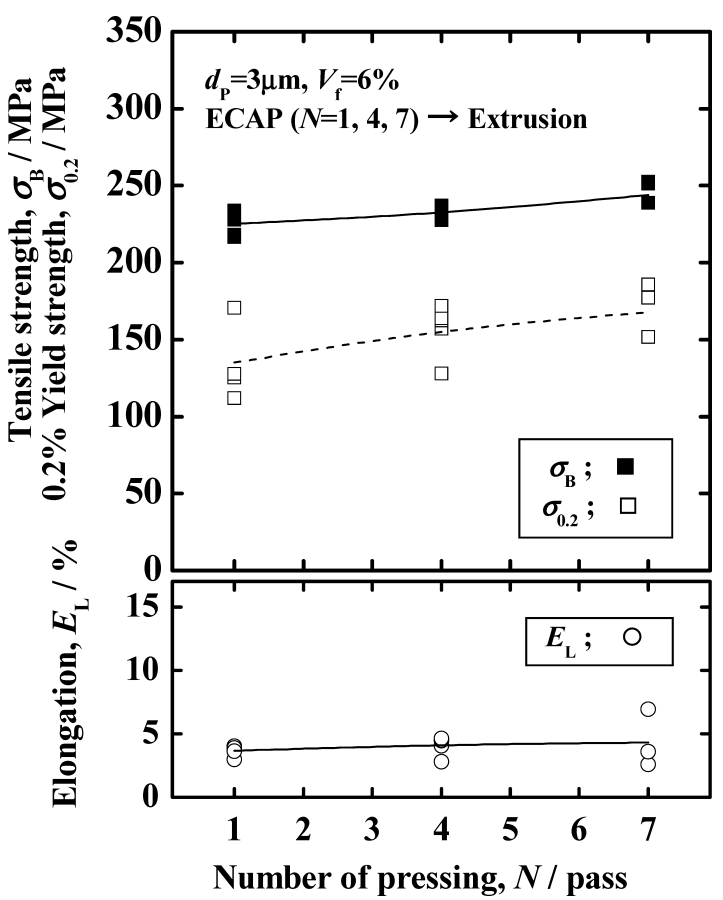

Fig. 10 Room temperature mechanical properties of $\mathrm{SiC}_{\mathrm{P}} /$ $\mathrm{AZ31B}_{\text {chip }}$ composites extruded at $573 \mathrm{~K}$ after ECAP processing at $623 \mathrm{~K}$. $\left(N=1,4\right.$ and $\left.7, d_{\mathrm{P}}=3 \mu \mathrm{m}, V_{\mathrm{f}}=6 \%\right)$

十分に結合し, $\mathrm{SiC}$ 粒子周囲マトリックスの加工硬化領域屯 広く均一に分布していることが示唆される。

次に室温における引張試験の代表的な応力一ひずみ線図を Fig. 9 に示す。 $\mathrm{SiC}$ 添加量に伴い, 弾性域での直線の傾きが 大きくなっていることから， $\mathrm{SiC}$ 粒子添加の複合化効果によ り ${ }^{28)}$ ，ヤング率が増加していることが期待される。そこで $\mathrm{SiC}$ 粒子を含まない $N=7$ 回施した $\mathrm{ECAP}-$ 熱間押出材の引張試験 片に直接，ストレインゲージを貼り，弾性率を測定した。そ の結果, $E=57 \mathrm{GPa}$ 之著しく高い值を示した。しかし降伏後 の塑性変形域に扔いては, $\mathrm{SiC}$ 添加量が増加する程, 最大応 力にまで到達する前に破断していることがわかる。

Fig. 10 に SiC 粒子径 $3 \mu \mathrm{m}$ で体積率 $6 \%$ の冷間圧粉体を $T_{\mathrm{ECAP}}=623 \mathrm{~K}$ で $N=1 \sim 7$ 回まで $\mathrm{ECAP}$ 加工を施した後に $T_{\mathrm{E}}=573 \mathrm{~K}$ で押出加工した ECAP- 熱間押出材の室温における 引張試験結果を示す。ECAP 回数が増加すると，引張強さお よび $0.2 \%$ 耐力ともに増加し, 伸び值も若干の増加傾向を示

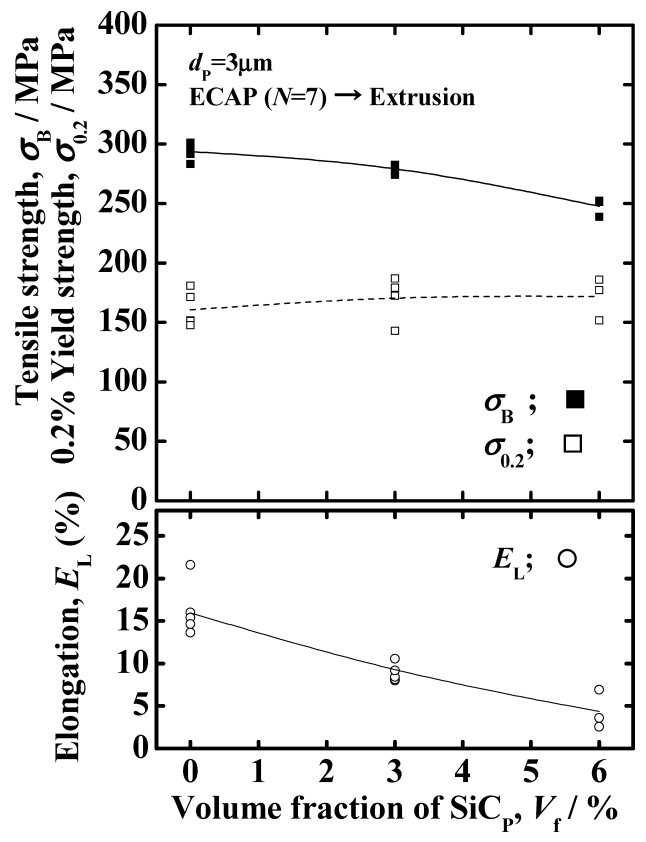

Fig. 11 Room temperature mechanical properties of $\mathrm{SiC}_{\mathrm{p}} /$ $\mathrm{AZ31B}_{\text {chip }}$ composites extruded at $573 \mathrm{~K}$ after ECAP processing at $623 \mathrm{~K} .\left(d_{\mathrm{P}}=3 \mu \mathrm{m}, N=7\right)$
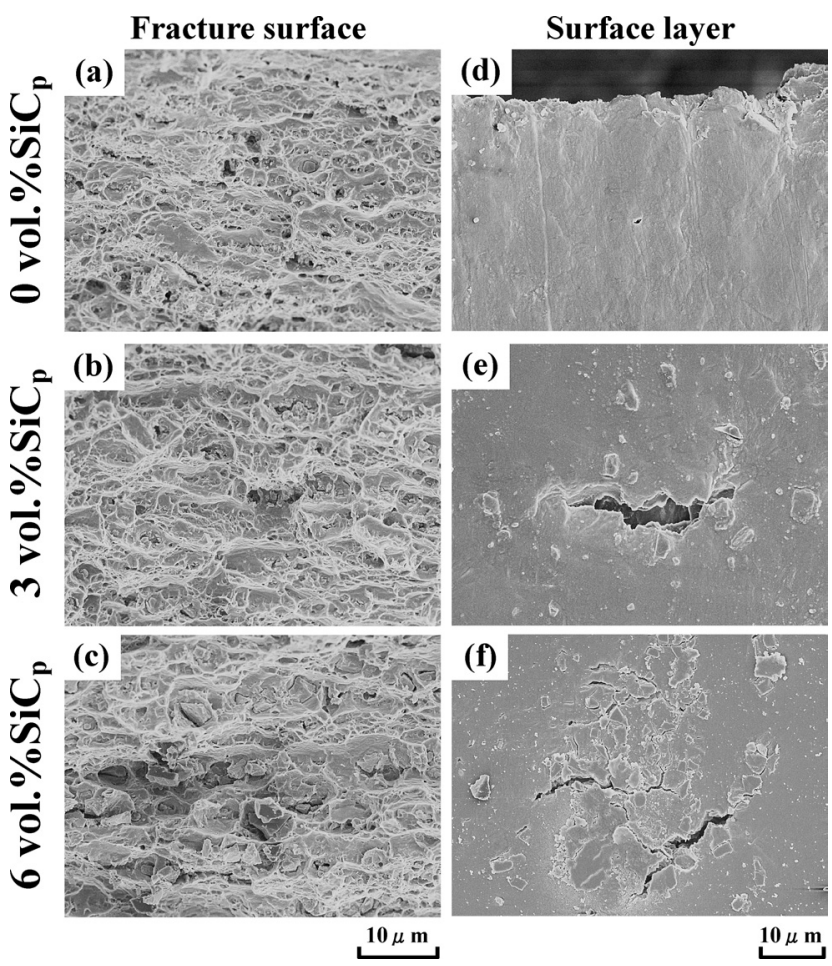

Fig. 12 SEM micrograph of specimens of the extruded samples of $\mathrm{SiC}_{\mathrm{P}} / \mathrm{AZ} 31 \mathrm{~B}_{\text {chip }}$ composites. (a), (b) and (c) show micrographs of fracture surfaces, while (d), (e) and (f) show surface layers.

した。これは ECAP加工によるせん断を多く加えることに よって冷間圧粉体の $\mathrm{SiC}$ 粒子凝集体が分断, かつ分散されて 大きな凝集体が減少すること, および結晶粒が微細化したこ となどが要因と考えられる。

Fig. 11 に $d_{\mathrm{P}}=3 \mu \mathrm{m}$ の $\mathrm{SiC}$ 粒子を $V_{\mathrm{f}}=0 \sim 6 \%$ 添加した 3 種 類の冷間圧粉体に対して, $T_{\mathrm{ECAP}}=623 \mathrm{~K}$ で $N=7$ 回の $\mathrm{ECAP}$ 加 


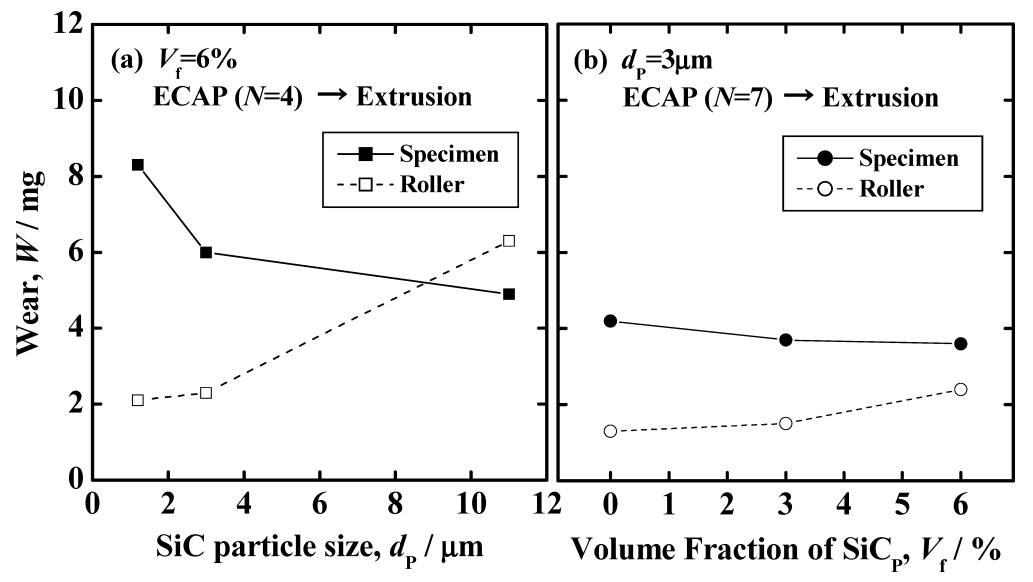

Fig. 13 Wear amount of roller and specimens of $\mathrm{SiC}_{\mathrm{P}} / \mathrm{AZ} 31 \mathrm{~B}_{\text {chip }}$ composites extruded at $573 \mathrm{~K}$ after ECAP processing at $623 \mathrm{~K}$. (a) $V_{\mathrm{f}}=6 \%, N=4$, (b) $d_{\mathrm{p}}=3 \mu \mathrm{m}, N=7$.

工を施した後に $T_{\mathrm{E}}=573 \mathrm{~K}$ で熱間押出した押出材の室温にお ける引張試験結果を示す。引張強さおよび伸び值は体積率の 増加とともに減少する傾向を示すが， $0.2 \%$ 耐力は若干の増 加を示す程度であり，大きな差異は認められなかった。そこ で $d_{\mathrm{p}}=3 \mu \mathrm{m}$ の $\mathrm{SiC}$ 粒子を体積率が $V_{\mathrm{f}}=0 \%, 3 \%$ および $6 \%$ と なるように添加した室温引張試験片の破断面中央部之破断近 傍の側面の SEM 組織観察結果を Fig. 12(a)〜 (f) に示す。 $\mathrm{SiC}$ 粒子を含まない体積率 $0 \%$ の場合では Fig. 12 (a), (d) 破 断部の近傍において亀裂は観察されないが, $\mathrm{SiC}$ 粒子を $V_{\mathrm{f}}=3 \%$ 添加した Fig. 12 (b)，（e）では， $\mathrm{SiC}$ 粒子間において亀 裂の発生していることがわかる。特に Fig. $12(\mathrm{c}),(\mathrm{f})$ の $V_{\mathrm{f}}=6 \%$ となるように添加した破断側面部においては, $\mathrm{SiC}$ 粒 子間の結合状態が弱く, 凝集体内部からも亀裂が発生し, 剥 離した破面形態が観察される。これらが Fig. 11 において引張 強さや伸びを低下させた要因の一つと考えられる。そこで次 に $\mathrm{SiC}$ 粒子の分散や分断の効果および有効性を調査するため に, $\mathrm{ECAP}$ 後に熱間押出加工を施した ECAP-熱間押出材に 対して, 摩擦摩耗試験を行った。

Fig. $13(\mathrm{a})$,（b）に $d_{\mathrm{P}}=1.2 \mu \mathrm{m}, 3 \mu \mathrm{m}$ および $11 \mu \mathrm{m}$ の $\mathrm{SiC}$ 粒 子を $V_{\mathrm{f}}=0$ から $6 \%$ の体積率になるまで添加した種々の冷間 圧粉体に $T_{\mathrm{ECAP}}=623 \mathrm{~K}$ で $N=4$ 回, および 7 回まで $\mathrm{ECAP}$ 加 工を施した後に $T_{\mathrm{E}}=573 \mathrm{~K}$ で熱間押出した押出材の摩擦摩耗 試験結果を示す。Fig. 13 (a), (b) の試験片の摩耗量は $d_{\mathrm{P}}$ およ び $V_{\mathrm{f}}$ の増大に伴い減少する傾向にある。しかしその反面, FC250 鋳鉄製回転ローラの相手材の摩耗量が増加している。 Fig. 13 (a) の $d_{\mathrm{P}}=11 \mu \mathrm{m}$ では ECAP- 熱間押出材の摩耗量と鋳 鉄製ローラの摩耗量が約 5 6 m $\mathrm{m}$ 程度とほぼ同程度に摩耗し ていることがわかった。また Fig. 13 (b) の $d_{\mathrm{P}}=3 \mu \mathrm{m}$ の場合で は, 繰返し $\mathrm{ECAP}$ 加工回数が $N=4$ 回よりあ $N=7$ 回施した $\mathrm{ECAP}$ - 熱間押出材の試験片の方が摩耗量は少なくなることが わかった。村田ら ${ }^{29)}$ は時効処理により析出物を密に分散する ことで，AZ91 合金の耐摩耗性を向上することを報告してい る。原ら ${ }^{27)}$ は $\mathrm{TiCN}$ 系サーメットに対して局所的に偏析があ る場合より屯微細かつ均質に混合したミクロ組織において, 耐摩耗性が高く，かつ相手材への攻撃性も低い之報告してお り, 本実験結果からも $N=4$ よりも $N=7$ の ECAP_熱間押出 材に打いて, $\mathrm{SiC}$ 粒子の均質混合之凝集体の分断や分散の有 無が摩耗量に大きく影響しているといえる。

\section{4. 結言}

$\mathrm{AZ} 31 \mathrm{~B}$ マグネシウム合金切削チップと $\mathrm{SiC}$ 粒子を混合した 冷間圧粉体における $\mathrm{SiC}$ 粒子の凝集体の分断および均一分散 を促進するため, 熱間押出, ECAP およびその組合せによる 強せん断加工の効果をミクロ組織抢よび機械的性質の評価に より検討した結果を以下に示す。

（1） AZ31B 切削チップに平均粒子径がそれぞれ $d_{\mathrm{P}}=1.2 \mu \mathrm{m}$, $3 \mu \mathrm{m}$ および $11 \mu \mathrm{m}$ の $\mathrm{SiC}$ 粒子を体積率で $V_{\mathrm{f}}=0 \sim 6 \%$ まで混合 した冷間圧粉体に熱間押出加工を施すことにより，切削チッ プの表面に薄く付着した $\mathrm{SiC}$ 粒子は均一な分散挙動を示す。 しかし SiC 粒子径が比較的小さい $3 \mu \mathrm{m}$ 以下では，切削チッ プ相互の界面の 3 重点に塊状に導入された凝集体を完全に分 断するまでには至らなかった。

（2） $\mathrm{SiC}$ 粒子が $3 \mu \mathrm{m}$ で体積率を $6 \%$ とした冷間圧粉体を Route $\mathrm{B}_{\mathrm{A}}$ で $N=7$ 回まで繰返し ECAP 加工した後に熱間押出 加工を加えた ECAP- 熱間押出材は, ECAP 回数の増大ととも に $\mathrm{SiC}$ 粒子凝集体の分断および分散することで, $\mathrm{SiC}$ 粒子を ほぼ均一に分散した AZ31B マグネシウム合金切削チップ - $\mathrm{SiC}$ 粒子複合材を得ることができた。またマトリックスの平均結 晶粒径は約 $2 \mu \mathrm{m}$ と極めて微細化し， $\sigma_{\mathrm{B}}, \sigma_{0.2}$ あ向上した。

（3）ローラ・チップ型摩擦摩耗試験機で評価した結果, $\mathrm{ECAP}$ 回数の大きい $\mathrm{ECAP}-$ 熱間押出材の方が, $\mathrm{SiC}$ 粒子の均 質混合と凝集体の分断や分散により, 耐摩耗性が向上した。

\section{謝 辞}

本研究の遂行に際してご指導を賜りました長岡技術科学大 学 小島 陽 学長に心より感謝致します。また本研究の一 部は文部科学省科学研究補助金・基盤研究 (C) (課題番号 16560610）の援助により行われたものである。

\section{参 考 文 献}

1）鎌土重晴: 塑性と加工，48（2007), 358-366.

2）小島 陽，鎌土重晴：自動車技術， 56 (2002), 21-27.

3）西田義則：金属基複合材料入門，コロナ社，東京，(2001，4-9.

4）金 埈洙, 菅又 信, 金子純一：日本金属学会誌， 55 (1991), 521-528.

5) M. Y. Zheng, K. Wu, S. Kamado and Y. Kojima: Mater. Sci. Eng., A348 (2003), 67-75.

6）長田貢一, 彦坂武夫, 木村與司雄: 愛知県産業技術研究所研究 報告, 3 (2004), 14-17. 
7) S. Ugandhar, M. Gupta and S. K. Sinha: Composite Structures, 72 (2006), 266-272.

8) Z. Xiuqing, L. Lihua, M. Naiheng, W. Haowei: Mater. Chem. Phys., 96 (2006), 9-15.

9）鎌倉光利，戸梶惠郎，植松美彦：材料， 55 (2006), 55-60.

10）近藤勝義：軽金属, $\mathbf{5 4}$ (2004), 187-191

11）鎌土重晴，小島 陽：塑性之加工，44 (2003), 3-9.

12）千野靖正，馬㴊 守：軽金属, 57 (2007), 250-255.

13）佐藤 寿, 會田哲夫, 高辻則夫, 松木賢司, 室谷和雄：軽金属, $\mathbf{5 4}$ (2004), 14-18

14）會田哲夫, 高辻則夫, 松木賢司, 小原 卓, 鎌土重晴：軽金属, 55 (2005), 400-404

15）會田哲夫, 高辻則夫, 松木賢司, 小原 卓, 鎌土重晴：軽金属, 56 (2006), 166-171.

16）會田哲夫, 高辻則夫, 松木賢司, 鎌土重晴, 小島 陽：軽金属, 54 (2004), 532-537.

17）近藤勝義，都筑律子，杜 文博，鎌土重晴：まてりあ，43 (2004), 275-280.

18）藤井徳雄，金子貫太郎，塩崎修司，近藤勝義，護法良憲：クリ モト技報，55（2006），24-29
19) S. Mizunuma: Mater. Sci. Forum, 503-504（2006), 185-190.

20) Z. Horita, T. Fujinami and T. G. Langdon: Mater. Sci Eng., A318 (2001), 34-41

21） W. J. Kim and Y. K. Sa: Scripta Materialia, 54 (2006), 1391-1395.

22）古島 剛, 清水徹英, 真鍋健一：塑性と加工，48（2007）, 412-416.

23） T. Mukai, T. G. Nieh and K. Higashi: Mat. Sci. Forum, 243-245 (1997), 321-326.

24）堀田善治, 古川 稔, T. G. Langdon, 根本 實：まてりあ, 37 (1998), 767-774.

25) Y. Iwahashi, J. Wang, Z. Horita, M. Nemoto and T. G. Langdon: 35 (1996), 143-146.

26) T. Aida, K. Matsuki, Z. Horita and T. G. Langdon: Scripta Materialia, 44 (2001), 575-579.

27）原＼cjkstart恭，松木賢司，會田哲夫：トライボロジスト， 47 (2002), 204-214.

28） R. A. Saravanan and M. K. Surappa: Mat. Sci. Eng., A276 (2000), 108-116.

29）村田彰宏, 谷川洋平, 松岡 敬, 坂口一彦, 渡辺博行, 向井敏 司：材料, 54 (2005)，90-96. 